\title{
Implementing Lean Manufacturing System: ISM Approach
}

\author{
Naveen Kumar $^{3}$, Sanjay Kumar ${ }^{2}$, Abid Haleem ${ }^{3}$, Pardeep Gahlot ${ }^{4}$ \\ ${ }^{1}$ Maharishi Dyanand University, ${ }^{2}$ Bhagwan Parsuram College of Engineering, \\ ${ }^{3}$ Jamia Millia Islamia, ${ }^{4}$ Maharishi Dyanand University (India)
}

naveenkumar42906@gmail.com,skbhardwaj1971191@gmail.com, Haleem.abid@gmail.com,pardeepgablot@gmail.com

\section{Abstrac:}

Purpose Lean Manufacturing System has emerged as an important area of research in Indian context. The requirement of Lean Manufacturing has increased due to defects in products (semi finished and finished) and subsequent increase in cost. In this context, this study is an attempt to develop a structural model of the variables, important to implement Lean Manufacturing System in Indian automobile industry.

Design/Methodalogy/Approadr Various variables of lean manufacturing system implementation have been identified from literature review and experts' opinions. Contextual relationship among these identified variables has been set after carrying out brainstorming session. Further, classification of the variables has been carried out based upon the driving power and dependence. In addition to this, a structural model of variables to implement lean concept in Indian automobile industry has also been developed using Interpretive Structural Modeling (ISM) technique. Questionnaire based survey has also been conducted to rank these variables.

Findings: Eighteen variables have been identified from the literature and subsequent discussions with experts. Out of which, nine variables have been identified as dependent and nine variables have been identified as driver. No variable has been identified as linkage variable and autonomous variable. From the model developed, 'Relative cost benefits' has been identified as 
top level dependent variable and top management commitment as bottom level most independent variable.

Research limitations/implications: The model so developed is a hypothetical model based upon experts' opinions. The conclusions so drawn may be further modified to apply in real situation.

Practical implication: Clear understanding of interactions among these variables will help organizations to prioritize and manage these variables more effectively and efficiently to draw advantage from lean manufacturing system implementation.

Originality/value Through this paper we contribute to identify the variables to implement lean manufacturing system in Indian automobile industry and prioritize them. The structured model developed will help to understand interdependence of the variables of lean manufacturing system implementation.

Keyword: Interpretive Structural Modeling(ISM), Lean Manufacturing System

\section{Introduction}

Lean manufacturing is a conceptual framework recognized in many industrial companies since the early 1990s (Womack \& Jones, 1994). Lean manufacturing can be best explained as eliminating waste in a production process (Womak \& Jones, 1996). Anything (process or product tangible and intangible) that does not add value to the end product is called waste (Henderson \& Larco, 2003). Essentially, lean manufacturing seeks to produce a product that is exactly what the customer wants at right time, minimizing all non-value added activities in the production (Womack \& Jones, 1994). When the time comes to begin the transformation to lean, management will need to get people together and making them aware what is going to happen, and what is expected (Henderson \& Larco, 2003). The lean transition is, an organizational culture transition to manage lean, specifically during the initial phases, is more about managing the change process than managing lean tools and techniques (Csokasy \& Parent, 2007). Lean production is a socio-technical system (Shah \& Ward, 2007), which is viewed as a philosophy that takes care of both technical and cultural aspects (Bhasin \& Burcher, 2006). Efficiency of manufacturing has been an objective in development of Toyota Production System (TPS) (Holweg, 2007).

\subsection{Objectives of the research}

During the preliminary literature review, it has been observed that less research work is reported on lean manufacturing system implementation in Indian context; identification of variables relevant to Indian automobile industry need to be done; and dynamics of these 
variables needs to be examined.

The gaps identified in the literature review gave direction to carry out the present research. The objectives of the research are:

- To identify and rank the variables in implementation of lean manufacturing system;

- To establish the relationship among these identified variables; and

- To develop a structural model using ISM.

- To carry out MICMAC analysis.

\subsection{Organization of Paper}

The next section discusses the identification of the variables in the implementation of lean manufacturing system in Indian automobile industry, which is followed by the discussion of the ISM methodology to model these variables.

MICMAC analysis of developed ISM model has been carried out subsequently to understand the driving power and dependence of the variables. Finally, the conclusions of research have been presented.

\section{Identification of variables of lean manufacturing system implementation}

Today, many organizations are enthusiastic to adopt lean manufacturing in order to improve their performance in this competitive globalized market where uncertainty is prevalent (Wong, Wong \& Ali, 2009a). Suppliers have been reported as a critical factor for the success of lean manufacturing responsible to supply improved quality of raw material (Keller, Fouad \& Zaitri, 1991). Performance measures should have top management and involve employees in development (Ghalavini \& James, 1996) leading to cultural change reported very important in lean manufacturing system implementation. Material handling has been also a crucial factor in lean manufacturing because the cost attributed to material handling has been estimated in a study between $15 \%$ and $70 \%$ of the total manufacturing operation expenses (Tompkins, White, Bozer, Frazelle, Tanchoco \& Trevino, 1996; Karlsson \& Åhlström, 1996), which may be because of poor layout of facilities leading to several deteriorating effects such as excessive work-in-process inventories, and low or unbalanced equipment utilization (Heragu, 1997). Another element of lean manufacturing, cellular layout, was studied in small scale industry (Pattanaik \& Sharma, 2009). A list of bundles of lean practices includes JIT(Just in Time), total quality management, total preventative maintenance, and human resource management, pull, flow, low setup, controlled processes, productive maintenance and involved employees (Mckone, Schroeder \& Cua, 1999; Swink, Narasimha \& Kim, 2005; Linderman, Schroeder \& Choo, 2006, Shah \& Ward, 2007). Appropriate scheduling methods 
have been reported as critical factor to optimize the use of resources. Further, pull methods (like Kanban) and lot size reduction have been identified as commonly used ways to reduce storage and inventories and to avoid overproduction (Poppendieck, 2002). Standardization of work processes is required for efficient, safe work methods and to eliminate wastes (Kasul \& Motwani, 1997). Reduced complexity (complicated product and processes) increases chances for variations and errors. By reducing the number of parts; material types in products; simplifying process steps; and eliminating equipment with the unnecessary features, we may tend to reduce complexity. Importance of communication and management support in lean has been examined by (Worley \& Doolen, 2006). Lean manufacturing system implementation variables identification in Indian automobile sector and establishing mutual relationship had been carried out by conducting brainstorming session with experts after circulating literature of lean manufacturing among the experts. In this session, the experts had identified 18 most important variables for the implementation of lean manufacturing and identification contextual relationship among these identified variables had been carried out. These identified variables have been listed in Table 1.

\begin{tabular}{|c|c|c|}
\hline S.N. & $\begin{array}{l}\text { Lean Manufacturing System } \\
\text { Implementation Variables }\end{array}$ & Researchers \\
\hline 1 & Quality of human resources & $\begin{array}{l}\text { Yu Lin \& Hui Ho (2008); Åhlström (1998); Womack, Jones \& } \\
\text { Roos (1990). }\end{array}$ \\
\hline 2 & Relative cost benefit's & Emiliani, (2001). \\
\hline 3 & Effective scheduling to reduce waiting time & $\begin{array}{l}\text { Hayes \& Wheelwright (1984); Skinner (1974); Poppendieck } \\
\text { (2002); Heizer \& Render (2006); Womack et al. (1990). }\end{array}$ \\
\hline 4 & $\begin{array}{l}\text { Part standardization to reduce complexity } \\
\text { and excessive processing }\end{array}$ & Kasul \& Motwani (1997); Liker (2004). \\
\hline 5 & $\begin{array}{l}\text { Efficient use of newer more efficient } \\
\text { technology }\end{array}$ & Edwards (1996). \\
\hline 6 & Effective visual control & Katayama \& Bennett (1996); Pattanaik \& Sharma (2009) \\
\hline 7 & Increased safety and ergonomics & Walder, Karlin \& Kerk (2007). \\
\hline 8 & Collaborative decision making & Kasul \& Motwani (1997); Ahuja (1996). \\
\hline 9 & Proper utilization of floor space & Heragu (1997). \\
\hline 10 & Minimization of defects & LEI (2003). \\
\hline 11 & Value addition & Womack \& Jones (1996). \\
\hline 12 & Customer involvement in quality program & Panizzolo (1998). \\
\hline 13 & Capability and competence of sales network & Womack \& Jones (1996). \\
\hline 14 & Appropriate quality of manufacturing facilities & EPA (2003). \\
\hline 15 & Improved quality of raw material & $\begin{array}{l}\text { Nakamura, Sakakibara \& Schroeder (1998); Forza (1996); } \\
\text { Shah \& Ward (2003); Taj (2008). }\end{array}$ \\
\hline 16 & Reduction in unnecessary inventory & Liker (2004). \\
\hline 17 & Top management commitment & Hamel \& Prahald (1989) \\
\hline 18 & $\begin{array}{l}\text { Optimization of transportation and material } \\
\text { handling cost }\end{array}$ & $\begin{array}{l}\text { LEI (2003); Karlsson \& Åhlström (1996); Womack et al. } \\
\text { (1990). }\end{array}$ \\
\hline
\end{tabular}

Table 1. Variables Used in ISM Modeling of Lean Manufacturing System Implementation

A questionnaire based study had been carried out and respondents were asked to rank above variables on Likert scale of 1-5 (where 1 means "not important" and 5 means "most 
important"). Eighty eight questionnaires were sent to respondents, out of them sixty two questionnaires were received back and forty five questionnaires (Table 2) were considered for research work, where as seventeen questionnaires were discarded due to incompletion (Figure 1 and 2).

\begin{tabular}{|c|c|c|c|c|}
\hline \multirow{2}{*}{} & Professional Qualification & \multicolumn{3}{|c|}{ Work Experience } \\
\cline { 2 - 5 } & Graduate/Post Graduate & 3 & -- & -- \\
\hline \multirow{2}{*}{\begin{tabular}{c} 
Respondent from Academia \\
\cline { 2 - 5 }
\end{tabular}} & Ph.D & -- & 7 & 8 \\
\cline { 2 - 5 } & Graduate/ Post Graduate & 4 & 10 & 13 \\
\hline
\end{tabular}

Table 2. Respondent Categorization

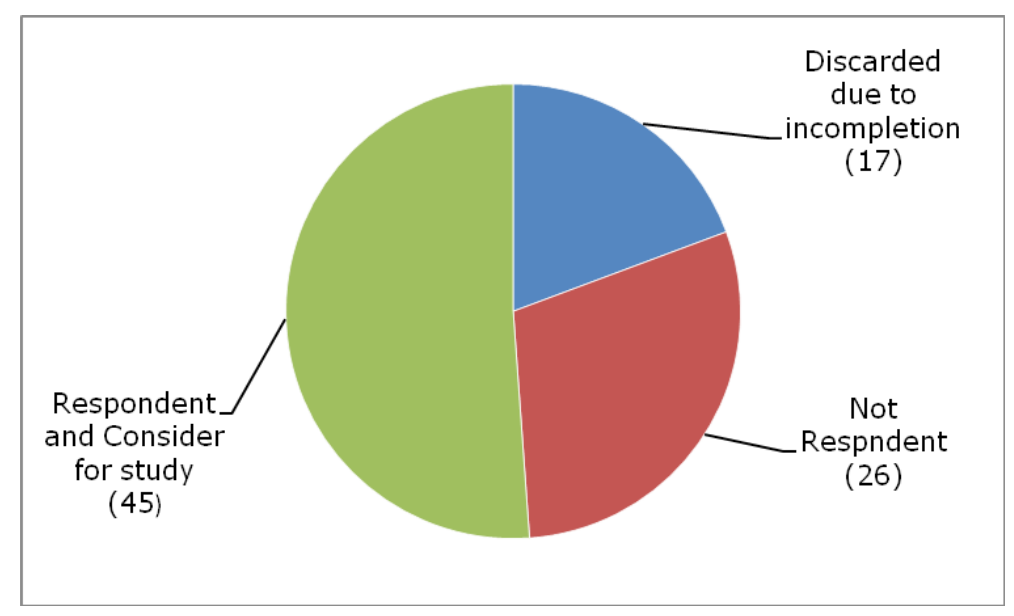

Figure 1. Responses of Questionaire Based Survey Carried Out

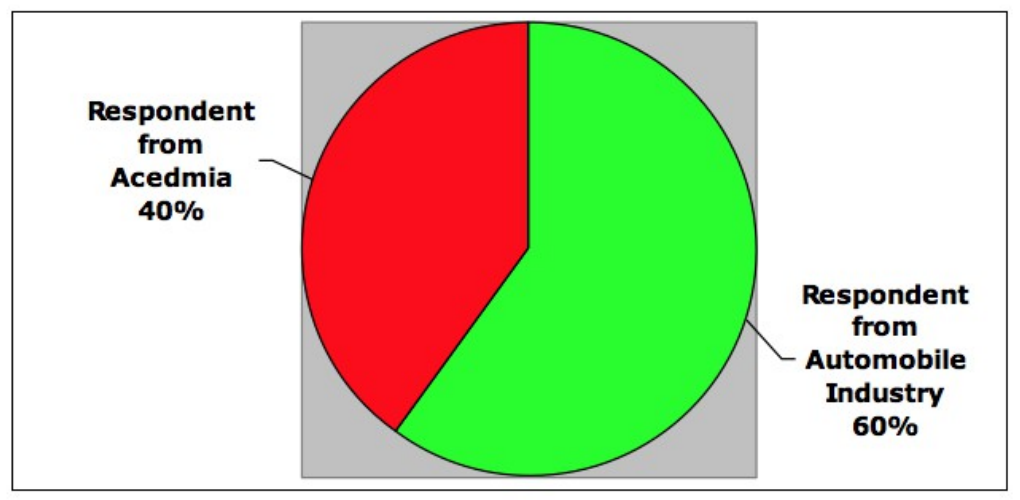

Figure 2. Respondent from Industries and Academics considered for the Study

The mean, variance and rank on the basis of mean value have been shown in Table 3. Variable number seventeen named as Top management commitment has been reported as "rank I" by the respondents. It is evident from Table 3 that the variable number one (Quality of human resources) and variable number ten (Minimization of defects) have the maximum variance of the responses. 


\begin{tabular}{|c|c|c|c|c|c|c|}
\hline Variables & Mean & $\begin{array}{c}\text { Standard Error } \\
\text { Mean }\end{array}$ & Trimmed Mean & $\begin{array}{c}\text { Standard } \\
\text { Deviation }\end{array}$ & Variance & Rank based on Mean \\
\hline 1 & 3.650 & 0.132 & 3.611 & 0.834 & 0.695 & XI \\
\hline 2 & 3.550 & 0.107 & 3.500 & 0.667 & 0.459 & XV \\
\hline 3 & 3.950 & 0.113 & 3.944 & 0.714 & 0.510 & III \\
\hline 4 & 3.775 & 0.098 & 3.750 & 0.619 & 0.384 & VI \\
\hline 5 & 3.700 & 0.109 & 3.667 & 0.687 & 0.472 & IX \\
\hline 6 & 3.650 & 0.105 & 3.611 & 0.662 & 0.438 & XII \\
\hline 7 & 3.750 & 0.099 & 3.722 & 0.630 & 0.397 & VII \\
\hline 8 & 3.625 & 0.106 & 3.583 & 0.667 & 0.446 & XIII \\
\hline 9 & 3.975 & 0.116 & 3.972 & 0.733 & 0.538 & II \\
\hline 10 & 3.875 & 0.130 & 3.861 & 0.822 & 0.676 & V \\
\hline 11 & 3.475 & 0.094 & 3.416 & 0.598 & 0.358 & XVII \\
\hline 12 & 3.525 & 0.113 & 3.472 & 0.716 & 0.512 & XVI \\
\hline 13 & 3.425 & 0.094 & 3.361 & 0.594 & 0.353 & XVIII \\
\hline 14 & 3.675 & 0.121 & 3.639 & 0.764 & 0.584 & X \\
\hline 15 & 3.600 & 0.112 & 3.556 & 0.709 & 0.503 & IV \\
\hline 16 & 3.950 & 0.129 & 3.944 & 0.815 & 0.614 & XIV \\
\hline 17 & 4.175 & 0.129 & 4.194 & 0.813 & 0.661 & I \\
\hline 18 & 3.750 & 0.112 & 3.722 & 0.707 & 0.500 & VIII \\
\hline
\end{tabular}

Table 3. Mean and Variance of the Variables

\section{Interpretative Structural Modeling (ISM)}

ISM may be used for identifying and summarizing relationships among specific variables, which define a problem or an issue (Warfield, 1974; Sage, 1977). It provides us a means by which order may be imposed on the complexity of such variables (Mandal \& Deshmukh, 1994; Jharkharia \& Shankar, 2005; Luthra, Kumar, Kumar \& Haleem, 2011). The ISM is interpretive as the judgment of the selected group for the study decides whether and how the factors are interrelated. This section deals with discussion of ISM methodology and MICMAC. The various steps involved in the ISM methodology are as follows:

Step 1: Variables affecting the system are listed; in our research work factors to implement lean manufacturing system in Indian automobile industry have been identified as variables.

Step 2: From the variable identified in step 1, contextual relationship among variables are examined.

Step 3: A Structural Self-Interaction Matrix (SSIM) is developed for variables, which indicates pair wise relationship among variables of the system under consideration.

Step 4: A reachability matrix is developed from the SSIM and the matrix is checked for transitivity. The transitivity of the contextual relationships is a basic assumption made in ISM. It states that if a variable $A$ is related to variable $B$ and variable $B$ is related to the variable $C$, then variable $A$ necessarily is related to variable $C$.

Step 5: The reachability matrix obtained in Step 4 is partitioned into different levels. 
Step 6: Based on the contextual relationships in the reachability matrix, a directed graph is drawn and the transitivity links are removed.

Step 7: The resultant digraph is converted into an Interpretive Structural Model by replacing variable nodes with statements.

\subsection{Structural Self-Interaction Matrix (SSIM) and Reachability Matrix}

In the present research for identifying the contextual relationship among the variables of the lean manufacturing system implementation, three experts from academia and four experts from automobile industry, were consulted. These experts from the academia and from the industry were well conversant with lean manufacturing system implementation variables in Indian automobile industry. Based on contextual relationship among the variables SSIM has been developed. Four symbols have been used to denote the direction of the relationship between the variables ( $i$ and $j$ ):

V- variable i will help to achieve variable j;

A- variable $\mathrm{j}$ will help to achieve variable $\mathrm{i}$;

$\mathbf{X}$ - variable i and j will help to achieve each other; and

O- variable $\mathrm{i}$ and $\mathrm{j}$ are unrelated.

The following Table 4 would explain the use of the symbols $V, A, X$, and $O$ in SSIM. Variable 1 leads to variable 18 so symbol ' $V$ ' has been given in the cell $(1,18)$; variable 17 leads to variable 1 so symbol ' $A$ ' has been given in the cell $(1,17)$; variable 1 and 13 lead to each other so symbol ' $X$ ' has been given in the cell $(1,13)$; variable 3 and 13 do not lead to each other so symbol ' $O$ ' has been given in the cell $(3,13)$ and so on. The SSIM has been transformed into a binary matrix, called the initial reachability matrix by substituting the symbols $V, A, X$, and $O$ by 0 and 1 applying following rules:

- If $(i, j)$ value in the SSIM is $V,(i, j)$ value in the reachability matrix will be 1 and $(j, i)$ value will be 0 ; for $\mathrm{V}(1,18)$ in $\operatorname{SSIM}, ~ ' 1$ ' has been given in cell $(1,18)$ and ' 0 ' in cell $(18,1)$ in initial reachability matrix.

- If $(i, j)$ value in the SSIM is $A,(i, j)$ value in the reachability matrix will be 0 and $(j, i)$ value will be 1 ; for $A(1,17)$ in SSIM, ' 0 ' has been given in cell $(1,17)$ and ' 1 ' in cell $(17,1)$ in initial reachability matrix.

- If $(i, j)$ value in the SSIM is $X,(i, j)$ value in the reachability matrix will be 1 and $(j, i)$ value will also be 1 ; for $X(1,13)$ in SSIM, ' 1 ' has been given in cell $(1,13)$ and ' 1 ' in cell $(13,1)$ also in initial reachability matrix. 
- If $(i, j)$ value in the SSIM is $O,(i, j)$ value in the reachability matrix will be 0 and $(j, i)$ value will also be 0 ; for $O(3,13)$ in SSIM, ' $O$ ' has been given in cell $(3,13)$ and ' $O$ ' in cell $(13,3)$ also in initial reachability matrix as shown in Table 5.

Then final reachability matrix is obtained by incorporating the transitivity as discussed in the ISM methodology. The final reachability matrix has been shown in Table 6.

\begin{tabular}{|c|c|c|c|c|c|c|c|c|c|c|c|c|c|c|c|c|c|}
\hline Variables & $\mathbf{1 8}$ & $\mathbf{1 7}$ & $\mathbf{1 6}$ & $\mathbf{1 5}$ & $\mathbf{1 4}$ & $\mathbf{1 3}$ & $\mathbf{1 2}$ & $\mathbf{1 1}$ & $\mathbf{1 0}$ & $\mathbf{9}$ & $\mathbf{8}$ & $\mathbf{7}$ & $\mathbf{6}$ & $\mathbf{5}$ & $\mathbf{4}$ & $\mathbf{3}$ & $\mathbf{2}$ \\
\hline 1 & $\mathrm{~V}$ & $\mathrm{~A}$ & $\mathrm{~V}$ & $\mathrm{~V}$ & $\mathrm{~V}$ & $\mathrm{X}$ & $\mathrm{X}$ & $\mathrm{V}$ & $\mathrm{V}$ & $\mathrm{V}$ & $\mathrm{X}$ & $\mathrm{V}$ & $\mathrm{V}$ & $\mathrm{V}$ & $\mathrm{V}$ & $\mathrm{V}$ & $\mathrm{V}$ \\
\hline 2 & $\mathrm{~A}$ & $\mathrm{~A}$ & $\mathrm{~A}$ & $\mathrm{~A}$ & $\mathrm{~A}$ & $\mathrm{~A}$ & $\mathrm{~A}$ & $\mathrm{~A}$ & $\mathrm{~A}$ & $\mathrm{~A}$ & $\mathrm{~A}$ & $\mathrm{~A}$ & $\mathrm{~A}$ & $\mathrm{~A}$ & $\mathrm{~A}$ & $\mathrm{~A}$ & \\
\hline 3 & $\mathrm{~V}$ & $\mathrm{~A}$ & $\mathrm{X}$ & $\mathrm{A}$ & $\mathrm{A}$ & $\mathrm{O}$ & $\mathrm{O}$ & $\mathrm{V}$ & $\mathrm{A}$ & $\mathrm{V}$ & $\mathrm{A}$ & $\mathrm{V}$ & $\mathrm{A}$ & $\mathrm{A}$ & $\mathrm{X}$ & & \\
\hline 4 & $\mathrm{~V}$ & $\mathrm{~A}$ & $\mathrm{~V}$ & $\mathrm{~A}$ & $\mathrm{~A}$ & $\mathrm{~A}$ & $\mathrm{~A}$ & $\mathrm{~V}$ & $\mathrm{~A}$ & $\mathrm{~V}$ & $\mathrm{~A}$ & $\mathrm{~V}$ & $\mathrm{~A}$ & $\mathrm{~A}$ & & & \\
\hline 5 & $\mathrm{~V}$ & $\mathrm{~A}$ & $\mathrm{~V}$ & $\mathrm{O}$ & $\mathrm{V}$ & $\mathrm{A}$ & $\mathrm{A}$ & $\mathrm{V}$ & $\mathrm{V}$ & $\mathrm{V}$ & $\mathrm{A}$ & $\mathrm{V}$ & $\mathrm{V}$ & & & \\
\hline 6 & $\mathrm{~V}$ & $\mathrm{~A}$ & $\mathrm{~V}$ & $\mathrm{O}$ & $\mathrm{O}$ & $\mathrm{A}$ & $\mathrm{O}$ & $\mathrm{V}$ & $\mathrm{V}$ & $\mathrm{V}$ & $\mathrm{A}$ & $\mathrm{V}$ & & & & \\
\hline 7 & $\mathrm{~A}$ & $\mathrm{~A}$ & $\mathrm{~A}$ & $\mathrm{~A}$ & $\mathrm{~A}$ & $\mathrm{~A}$ & $\mathrm{~A}$ & $\mathrm{~V}$ & $\mathrm{~A}$ & $\mathrm{~A}$ & $\mathrm{~A}$ & & & & & \\
\hline 8 & $\mathrm{~V}$ & $\mathrm{~A}$ & $\mathrm{~V}$ & $\mathrm{~V}$ & $\mathrm{~V}$ & $\mathrm{X}$ & $\mathrm{X}$ & $\mathrm{V}$ & $\mathrm{V}$ & $\mathrm{V}$ & & & & & & \\
\hline 9 & $\mathrm{~V}$ & $\mathrm{~A}$ & $\mathrm{~A}$ & $\mathrm{~A}$ & $\mathrm{~A}$ & $\mathrm{O}$ & $\mathrm{O}$ & $\mathrm{V}$ & $\mathrm{A}$ & & & & & & & \\
\hline 10 & $\mathrm{~V}$ & $\mathrm{~A}$ & $\mathrm{~V}$ & $\mathrm{~A}$ & $\mathrm{~A}$ & $\mathrm{~A}$ & $\mathrm{~A}$ & $\mathrm{~V}$ & & & & & & & & \\
\hline 11 & $\mathrm{~A}$ & $\mathrm{~A}$ & $\mathrm{~A}$ & $\mathrm{~A}$ & $\mathrm{~A}$ & $\mathrm{~A}$ & $\mathrm{~A}$ & & & & & & & & & \\
\hline 12 & $\mathrm{O}$ & $\mathrm{A}$ & $\mathrm{V}$ & $\mathrm{V}$ & $\mathrm{V}$ & $\mathrm{X}$ & & & & & & & & & & \\
\hline 13 & $\mathrm{~V}$ & $\mathrm{~A}$ & $\mathrm{~V}$ & $\mathrm{~V}$ & $\mathrm{~V}$ & & & & & & & & & & & \\
\hline 14 & $\mathrm{~V}$ & $\mathrm{~A}$ & $\mathrm{~V}$ & $\mathrm{O}$ & & & & & & & & & & & & \\
\hline 15 & $\mathrm{~V}$ & $\mathrm{~A}$ & $\mathrm{~V}$ & & & & & & & & & & & & & \\
\hline 16 & $\mathrm{~V}$ & $\mathrm{~A}$ & & & & & & & & & & & & & \\
\hline 17 & $\mathrm{~V}$ & & & & & & & & & & & & & & \\
\hline 18 & & & & & & & & & & & & & & & \\
\hline
\end{tabular}

Table 4. Structural Self Interaction Matrix

\begin{tabular}{|c|c|c|c|c|c|c|c|c|c|c|c|c|c|c|c|c|c|c|}
\hline Variables & $\mathbf{1}$ & $\mathbf{2}$ & $\mathbf{3}$ & $\mathbf{4}$ & $\mathbf{5}$ & $\mathbf{6}$ & $\mathbf{7}$ & $\mathbf{8}$ & $\mathbf{9}$ & $\mathbf{1 0}$ & $\mathbf{1 1}$ & $\mathbf{1 2}$ & $\mathbf{1 3}$ & $\mathbf{1 4}$ & $\mathbf{1 5}$ & $\mathbf{1 6}$ & $\mathbf{1 7}$ & $\mathbf{1 8}$ \\
\hline 1 & 1 & 1 & 1 & 1 & 1 & 1 & 1 & 1 & 1 & 1 & 1 & 1 & 1 & 1 & 1 & 1 & 0 & 1 \\
\hline 2 & 0 & 1 & 0 & 0 & 0 & 0 & 0 & 0 & 0 & 0 & 0 & 0 & 0 & 0 & 0 & 0 & 0 & 0 \\
\hline 3 & 0 & 1 & 1 & 1 & 0 & 0 & 1 & 0 & 1 & 0 & 1 & 0 & 0 & 0 & 0 & 1 & 0 & 1 \\
\hline 4 & 0 & 1 & 1 & 1 & 0 & 0 & 1 & 0 & 1 & 0 & 1 & 0 & 0 & 0 & 0 & 1 & 0 & 1 \\
\hline 5 & 0 & 1 & 1 & 1 & 1 & 1 & 1 & 0 & 1 & 1 & 1 & 0 & 0 & 1 & 0 & 1 & 0 & 1 \\
\hline 6 & 0 & 1 & 1 & 1 & 0 & 1 & 1 & 0 & 1 & 1 & 1 & 0 & 0 & 0 & 0 & 1 & 0 & 1 \\
\hline 7 & 0 & 1 & 0 & 0 & 0 & 0 & 1 & 0 & 0 & 0 & 1 & 0 & 0 & 0 & 0 & 0 & 0 & 0 \\
\hline 8 & 1 & 1 & 1 & 1 & 1 & 1 & 1 & 1 & 1 & 1 & 1 & 1 & 1 & 1 & 1 & 1 & 0 & 1 \\
\hline 9 & 0 & 1 & 0 & 0 & 0 & 0 & 1 & 0 & 1 & 0 & 1 & 0 & 0 & 0 & 0 & 0 & 0 & 1 \\
\hline 10 & 0 & 1 & 1 & 1 & 0 & 0 & 1 & 0 & 1 & 1 & 1 & 0 & 0 & 0 & 0 & 1 & 0 & 1 \\
\hline 11 & 0 & 1 & 0 & 0 & 0 & 0 & 0 & 0 & 0 & 0 & 1 & 0 & 0 & 0 & 0 & 0 & 0 & 0 \\
\hline 12 & 1 & 1 & 0 & 1 & 1 & 0 & 1 & 1 & 0 & 1 & 1 & 1 & 1 & 1 & 1 & 1 & 0 & 0 \\
\hline 13 & 1 & 1 & 0 & 1 & 1 & 1 & 1 & 1 & 0 & 1 & 1 & 1 & 1 & 1 & 1 & 1 & 0 & 1 \\
\hline 14 & 0 & 1 & 1 & 1 & 0 & 0 & 1 & 0 & 1 & 1 & 1 & 0 & 0 & 1 & 0 & 1 & 0 & 1 \\
\hline 15 & 0 & 1 & 1 & 1 & 0 & 0 & 1 & 0 & 1 & 1 & 1 & 0 & 0 & 0 & 1 & 1 & 0 & 1 \\
\hline 16 & 0 & 1 & 1 & 0 & 0 & 0 & 1 & 0 & 1 & 0 & 1 & 0 & 0 & 0 & 0 & 1 & 0 & 1 \\
\hline 17 & 1 & 1 & 1 & 1 & 1 & 1 & 1 & 1 & 1 & 1 & 1 & 1 & 1 & 1 & 1 & 1 & 1 & 1 \\
\hline 18 & 0 & 1 & 0 & 0 & 0 & 0 & 1 & 0 & 0 & 0 & 1 & 0 & 0 & 0 & 0 & 0 & 0 & 1 \\
\hline
\end{tabular}

Table 5. Initial Reachability Matrix 


\begin{tabular}{|c|c|c|c|c|c|c|c|c|c|c|c|c|c|c|c|c|c|c|c|}
\hline Variables & 1 & 2 & 3 & 4 & 5 & 6 & 7 & 8 & 9 & 10 & 11 & 12 & 13 & 14 & 15 & 16 & 17 & 18 & $\begin{array}{l}\text { Driver } \\
\text { Power }\end{array}$ \\
\hline 1 & 1 & 1 & 1 & 1 & 1 & 1 & 1 & 1 & 1 & 1 & 1 & 1 & 1 & 1 & 1 & 1 & 0 & 1 & 17 \\
\hline 2 & 0 & 1 & 0 & 0 & 0 & 0 & 0 & 0 & 0 & 0 & 0 & 0 & 0 & 0 & 0 & 0 & 0 & 0 & 1 \\
\hline 3 & 0 & 1 & 1 & 1 & 0 & 0 & 1 & 0 & 1 & 0 & 1 & 0 & 0 & 0 & 0 & 1 & 0 & 1 & 8 \\
\hline 4 & 0 & 1 & 1 & 1 & 0 & 0 & 1 & 0 & 1 & 0 & 1 & 0 & 0 & 0 & 0 & 1 & 0 & 1 & 8 \\
\hline 5 & 0 & 1 & 1 & 1 & 1 & 1 & 1 & 0 & 1 & 1 & 1 & 0 & 0 & 1 & 0 & 1 & 0 & 1 & 12 \\
\hline 6 & 0 & 1 & 1 & 1 & 0 & 1 & 1 & 0 & 1 & 1 & 1 & 0 & 0 & 0 & 0 & 1 & 0 & 1 & 10 \\
\hline 7 & 0 & 1 & 0 & 0 & 0 & 0 & 1 & 0 & 0 & 0 & 1 & 0 & 0 & 0 & 0 & 0 & 0 & 0 & 3 \\
\hline 8 & 1 & 1 & 1 & 1 & 1 & 1 & 1 & 1 & 1 & 1 & 1 & 1 & 1 & 1 & 1 & 1 & 0 & 1 & 17 \\
\hline 9 & 0 & 1 & 0 & 0 & 0 & 0 & 1 & 0 & 1 & 0 & 1 & 0 & 0 & 0 & 0 & 0 & 0 & 1 & 5 \\
\hline 10 & 0 & 1 & 1 & 1 & 0 & 0 & 1 & 0 & 1 & 1 & 1 & 0 & 0 & 0 & 0 & 1 & 0 & 1 & 9 \\
\hline 11 & 0 & 1 & 0 & 0 & 0 & 0 & 0 & 0 & 0 & 0 & 1 & 0 & 0 & 0 & 0 & 0 & 0 & 0 & 2 \\
\hline 12 & 1 & 1 & $1^{*}$ & 1 & 1 & $1 *$ & 1 & 1 & $1 *$ & 1 & 1 & 1 & 1 & 1 & 1 & 1 & 0 & $1^{*}$ & 17 \\
\hline 13 & 1 & 1 & $1 *$ & 1 & 1 & 1 & 1 & 1 & $1 *$ & 1 & 1 & 1 & 1 & 1 & 1 & 1 & 0 & 1 & 17 \\
\hline 14 & 0 & 1 & 1 & 1 & 0 & 0 & 1 & 0 & 1 & 1 & 1 & 0 & 0 & 1 & 0 & 1 & 0 & 1 & 10 \\
\hline 15 & 0 & 1 & 1 & 1 & 0 & 0 & 1 & 0 & 1 & 1 & 1 & 0 & 0 & 0 & 1 & 1 & 0 & 1 & 10 \\
\hline 16 & 0 & 1 & 1 & $1^{*}$ & 0 & 0 & 1 & 0 & 1 & 0 & 1 & 0 & 0 & 0 & 0 & 1 & 0 & 1 & 8 \\
\hline 17 & 1 & 1 & 1 & 1 & 1 & 1 & 1 & 1 & 1 & 1 & 1 & 1 & 1 & 1 & 1 & 1 & 1 & 1 & 18 \\
\hline 18 & 0 & 1 & 0 & 0 & 0 & 0 & 1 & 0 & 0 & 0 & 1 & 0 & 0 & 0 & 0 & 0 & 0 & 1 & 4 \\
\hline Dependence & 5 & 18 & 13 & 13 & 6 & 7 & 16 & 5 & 14 & 10 & 17 & 5 & 5 & 7 & 6 & 13 & 1 & 15 & \\
\hline
\end{tabular}

Table 6. Final Reachability Matrix

\subsection{Level Partitions}

\begin{tabular}{|c|c|c|c|c|}
\hline Variables & Reachability Set & Antecedent Set & $\begin{array}{c}\text { Intersection } \\
\text { Set }\end{array}$ & Level \\
\hline 1 & $1,2,3,4,5,6,7,8,9,10,11,12,13,14,15,16,18$ & $1,8,12,13,17$ & $1,8,12,13$ & \\
\hline 2 & 2 & $1,2,3,4,5,6,7,8,9,10,11,12,13,14,15,16,17$ & 2 & I \\
\hline 3 & $2,3,4,7,9,11,16,18$ & $1,3,4,5,6,8,10,12,13,14,15,16,17$ & $3,4,16$ & \\
\hline 4 & $2,3,4,7,9,11,16,18$ & $1,3,4,5,6,8,10,12,13,14,15,16,17$ & $3,4,16$ & \\
\hline 5 & $2,3,4,5,6,7,9,10,11,14,16,18$ & $1,5,8,12,13,17$ & 5 & \\
\hline 6 & $2,3,4,6,7,9,10,11,16,18$ & $1,5,6,8,12,13,17$ & 6 & \\
\hline 7 & $2,7,11$ & $1,3,4,5,6,7,8,9,10,12,13,14,15,16,17,18$ & 7 & \\
\hline 8 & $1,2,3,4,5,7,8,9,10,11,12,13,14,15,16,18$ & $1,8,12,13,17$ & $1,8,12,13$ & \\
\hline 9 & $2,7,9,11,18$ & $1,3,4,5,6,8,9,10,12,13,14,15,16,17$ & 9 & \\
\hline 10 & $2,3,4,7,9,10,11,16,18$ & $1,5,6,8,10,12,13,14,15,17$ & 10 & \\
\hline 11 & 2,11 & $1,3,4,5,6,7,8,9,10,11,12,13,14,15,16,17,18$ & 11 & \\
\hline 12 & $1,2,3,4,5,6,7,8,9,10,11,12,13,14,15,16,18$ & $1,8,12,13,17$ & $1,8,12,13$ & \\
\hline 13 & $1,2,3,4,5,6,7,8,9,10,11,12,13,14,15,16,18$ & $1,8,12,13,17$ & $1,8,12,13$ & \\
\hline 14 & $2,3,4,7,9,10,11,14,16,18$ & $1,5,8,12,13,14,17$ & 14 & \\
\hline 15 & $2,3,4,7,9,10,11,15,16,18$ & $1,8,12,13,15,17$ & 15 & \\
\hline 16 & $2,3,4,7,9,11,16,18$ & $1,3,4,5,6,8,10,12,13,14,16,17$ & $3,4,16$ & \\
\hline 17 & $\begin{array}{l}1,2,3,4,5,6,7,8,9,10,11,12,13,14,15,16,17 \\
18\end{array}$ & 17 & 17 & \\
\hline 18 & $2,7,11,18$ & $1,3,4,5,6,8,9,10,12,13,14,15,16,17,18$ & 18 & \\
\hline
\end{tabular}

Table 7. Partitioning of Variables-Iteration 1 
The reachability set and antecedent set (Warfield, 1974) for each variable have been found out from final reachability matrix. Subsequently, the intersection set of these sets have been derived for all variables. The variable for which the reachability set and the intersection set are the same has been given the toplevel variable in the ISM hierarchy. From Table 7, it has been seen that Relative cost benefits has been found at Level 1 . The iteration has been continued till the level of each variable has been found out as shown in Table 8.

\begin{tabular}{|c|c|c|c|c|}
\hline Variables & Reachability Set & Antecedent Set & $\begin{array}{c}\text { Intersection } \\
\text { Set }\end{array}$ & Level \\
\hline 1 & $1,2,3,4,5,6,7,8,9,10,11,12,13,14,15,16,18$ & $1,8,12,13,17$ & $1,8,12,13$ & $x$ \\
\hline 2 & 2 & $\begin{array}{l}1,2,3,4,5,6,7,8,9,10,11,12,13,14,15,16, \\
17\end{array}$ & 2 & I \\
\hline 3 & $2,3,4,7,9,11,16,18$ & $1,3,4,5,6,8,10,12,13,14,15,16,17$ & $3,4,16$ & VI \\
\hline 4 & $2,3,4,7,9,11,16,18$ & $1,3,4,5,6,8,10,12,13,14,15,16,17$ & $3,4,16$ & VI \\
\hline 5 & $2,3,4,5,6,7,9,10,11,14,16,18$ & $1,5,8,12,13,17$ & 5 & IX \\
\hline 6 & $2,3,4,6,7,9,10,11,16,18$ & $1,5,6,8,12,13,17$ & 6 & VIII \\
\hline 7 & $2,7,11$ & $1,3,4,5,6,7,8,9,10,12,13,14,15,16,17,18$ & 7 & III \\
\hline 8 & $1,2,3,4,5,7,8,9,10,11,12,13,14,15,16,18$ & $1,8,12,13,17$ & $1,8,12,13$ & $\mathrm{x}$ \\
\hline 9 & $2,7,9,11,18$ & $1,3,4,5,6,8,9,10,12,13,14,15,16,17$ & 9 & $\mathrm{~V}$ \\
\hline 10 & $2,3,4,7,9,10,11,16,18$ & $1,5,6,8,10,12,13,14,15,17$ & 10 & VII \\
\hline 11 & 2,11 & $\begin{array}{l}1,3,4,5,6,7,8,9,10,11,12,13,14,15,16 \\
17,18\end{array}$ & 11 & II \\
\hline 12 & $1,2,3,4,5,6,7,8,9,10,11,12,13,14,15,16,18$ & $1,8,12,13,17$ & $1,8,12,13$ & $x$ \\
\hline 13 & $1,2,3,4,5,6,7,8,9,10,11,12,13,14,15,16,18$ & $1,8,12,13,17$ & $1,8,12,13$ & $x$ \\
\hline 14 & $2,3,4,7,9,10,11,14,16,18$ & $1,5,8,12,13,14,17$ & 14 & VIII \\
\hline 15 & $2,3,4,7,9,10,11,15,16,18$ & $1,8,12,13,15,17$ & 15 & VIII \\
\hline 16 & $2,3,4,7,9,11,16,18$ & $1,3,4,5,6,8,10,12,13,14,16,17$ & $3,4,16$ & VI \\
\hline 17 & $\begin{array}{l}1,2,3,4,5,6,7,8,9,10,11,12,13,14,15,16 \\
17,18\end{array}$ & 17 & 17 & $\mathrm{XI}$ \\
\hline 18 & $2,7,11,18$ & $1,3,4,5,6,8,9,10,12,13,14,15,16,17,18$ & 18 & IV \\
\hline
\end{tabular}

Table 8. Partitioning of Variables-Iteration 1

\section{Formation of ISM-based Model}

From the final reachability matrix, the structural model is generated known as diagraph. After removing the transitivity links and replacing the node numbers by statements, the ISM model is generated which has been shown in Figure 3. It has been observed from Figure 3 that 'Top management commitment' has been very significant variable for lean manufacturing system implementation in the Indian automobile industry as it comes at the base of the ISM hierarchy. 'Relative cost benefits' has been identified as the top level variable in the model. 


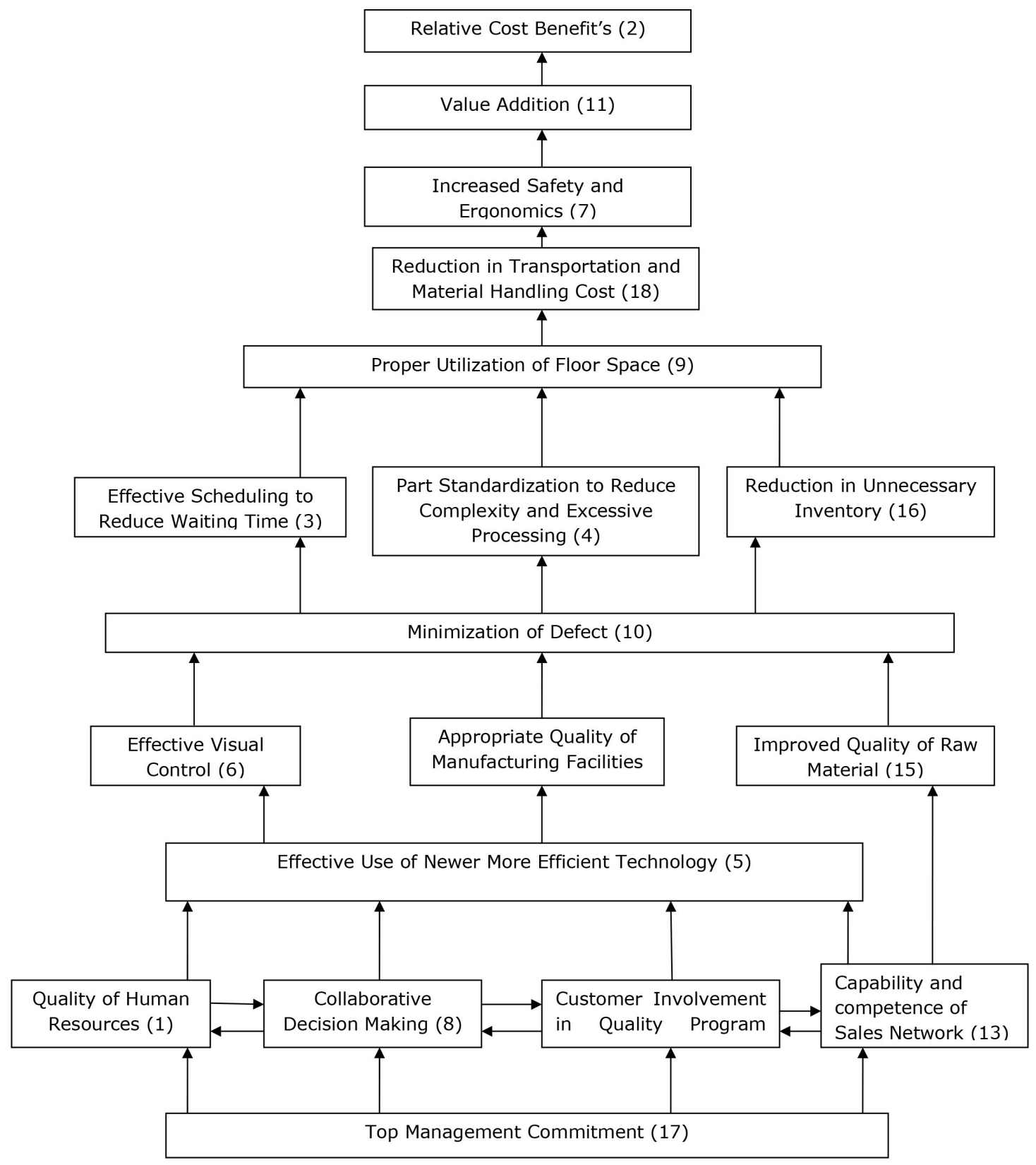

Figure 3. ISM Based Model of Variables of Lean Manufacturing System Implementation

\section{MICMAC Analysis}

Matrice d'Impacts croises-multipication applique' an classment (cross-impact matrix multiplication applied to classification) is abbreviated as MICMAC (Rajm Shankar \& Suhaib, 2008). MIC MAC analysis is done with the help of driving power and dependence power. In table 6 the driving power and dependence of each variable have been also shown. These driving power and dependence calculations have been used in the MIC MAC analysis to classify these variables into four groups of autonomous, dependent, linkage, and independent (driver) variables. The driver power-dependence diagram has been constructed which is shown in Figure 4.

- The first cluster consists of the autonomous variables that have weak driver power and weak dependence. No variable has been identified as autonomous variable. 
- Second cluster consists of the dependent variables that have weak driver power but strong dependence. Effective scheduling to reduce waiting time, Part standardization to reduce complexity and excessive processing, Reduction in unnecessary inventory, Proper utilization of floor space, Minimization of defects, Reduction in transportation and material handling cost, Increased safety and ergonomics, Value addition and Relative cost benefit's have been identified as dependent variables.

- Third cluster has the linkage variables that have strong driver power and also strong dependence. No variable has been found out as linkage variable in our study.

- Fourth cluster includes the independent variables having strong driving power but weak dependence. Top management commitment, Quality of human resources, Collaborative decision making, Customer involvement in quality program, Capability and competence of sales network, Effective use of newer more efficient technology, Improved quality of raw material, Effective visual control and Appropriate quality of manufacturing facilities have been identified as the driver variables.

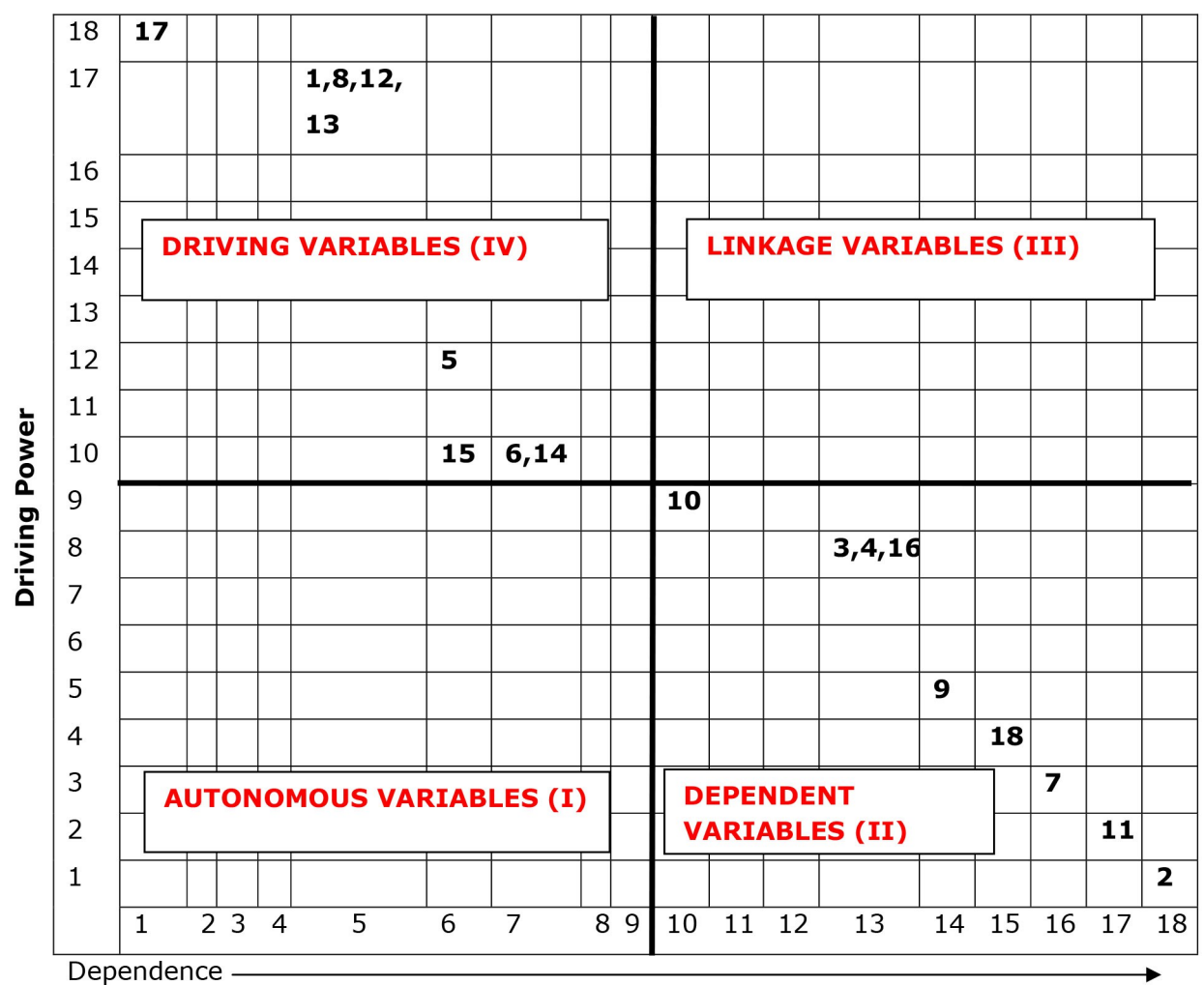

Figure 4. Clusters of Variables of Lean Manufacturing System in Indian Automobile Industry

\section{Discussions}

Lean Manufacturing System has been identified as an approach for improving performance of the processes and products. Eighteen factors to implement lean manufacturing in Indian automobile industry have been identified. Interpretive Structural Modeling (ISM) methodology has been used for finding contextual relationships among various variables to implement lean 
manufacturing in Indian automobile industry. A Model has been developed from ISM methodology. Nine variables have been identified as driver variables and nine as dependent variable. No variable has been identified as linkage variable and autonomous variable. Relative cost benefits has been identified as top level variables where as Top management commitment as most important bottom level variable.

\section{Limitations of the Study and Scope of Future Work}

Through lean manufacturing started in the automotive industry, it was reported to be applied in other sectors as well (Liker \& Morgan, 2006; Taj, 2008). The model developed in this research is based upon experts' opinions. The experts' opinion may be biased. The results of model may vary in real world setting. We have considered eighteen variables to implement lean manufacturing in Indian automobile industry. In case, a model needs to be developed for another / allied industry, some variables may be deleted or/ and added. Hypothesis testing may be done to test the validity of this hypothetical model. Structural Equation Modeling (SEM) may also be used to test the validity of structural model developed in this research. "Green" issues may be further included for developing a model for "lean and green" manufacturing system implementation although some variables identified in present research may be found relevant.

\section{Conclusions}

Waste minimization and improving efficiency have been identified as key objectives of lean manufacturing system implementation. Literature review and subsequent discussions with experts have helped to sort the factor relevant to lean manufacturing system implementation based upon their importance. Questionnaire based survey has been carried out to rank these identified factor followed by structural modeling. Top management commitment has been ranked the most important factor as a result of survey analysis and also has been identified as the most important bottom level factor in ISM hierarchy. MICMAC analysis has been utilized to classify the factors.

\section{References}

Ahuja, G. (1996). Does It Pay to Be Green? An Empirical Examination of the Relationship between Emissions Reduction and Firm Performance. Business Strategy and the Environment, 5(1), 30-37. http://dx.doi.org/10.1002/(SICI)1099-0836(199603)5:1<30::AID-BSE38>3.0.CO;2-Q

Åhlström, P., (1998). "Sequences in the implementation of lean production", European Management Journal 16, 327-334. http://dx.doi.org/10.1016/S0263-2373(98)00009-7

Bhasin, S., \& Burcher, P. (2006). Lean viewed as a philosophy. Journal of Manufacturing Technology Management, 17(1), 57-72. http://dx.doi.org/10.1108/17410380610639506 
Csokasy, D.L., \& Parent, P.D. (2007). Managing lean Manufacturing. Society of Manufacturing Engineers: Dearborn, MI TP07PUB2.

Edwards, D.K. (1996). Practical guidelines for lean manufacturing equipment. Product Inventory Manage J Second Quarter, 51-55

Emiliani, M.L. (2001). Redefining the focus of investment analysts. The TQM Magazine, 13(1), 34-51. http://dx.doi.org/10.1108/09544780110359400

EPA, (2003). Lean Manufacturing and the Enviroment, EPA 100-R-03-005. Retrieved from: www.epa.gov/innovation lean.htm. 1-12.

Forza, C., (1996). Work organization in lean production and traditional plants, what are the differences? International Journal of Operations \& Production Management, 16, 42-62. http://dx.doi.org/10.1108/01443579610109839

Ghalayini, A.M., \& James, S.N. (1996). The changing basis of performance measurement. International Journal of Operations \& Production Management, 16(8), 63-80. http://dx.doi.org/10.1108/01443579610125787

Hamel, G., \& Prahalad, C.K. (1989). Strategic Intent. Harvard Business Review, 67, 63-76.

Hayes, R.H., \& Wheelwright, S.C. (1984). Restoring our Competitive Edge: Competing Through Manufacturing. New York, NY: Wiley.

Heizer, J., \& Render, B., (2006). Operations Management. 8th ed. Upper Saddle River, NJ: Pearson Prentice-Hall.

Henderson, B.A., \& Larco, J.L. (2003). Lean Transformation: How to change your business into a lean enterprise. Virginia: Oaklea Press.

Heragu, S.S., (1997). Facilities Design. PWS Publishing Company, Boston, MA.

Holweg, M., (2007). The genealogy of lean production. Journal of operation management, 25(2), 420-437. http://dx.doi.org/10.1016/j.jom.2006.04.001

Jharkharia S., \& Shankar, R. (2005). IT enablement of supply chains: understanding the barriers. Journal of Enterprise Information Management, 18(1), 11-27. http://dx.doi.org/10.1108/17410390510571466

Karlsson, C., \& Åhlström, P. (1996). Assessing changes towards lean production. Int. J. Operation Production Management, 16(2), 24-41. http://dx.doi.org/10.1108/01443579610109820

Kasul, R.A., \& Motwani, J.G., (1997). Successful implementation of TPS in a manufacturing setting: a case study, Industrial Management \& Data Systems, 97, 274-279. http://dx.doi.org/10.1108/02635579710191707 
Katayama, H., \& Bennett, D., (1996). Lean production in a changing competitive world: a Japanese perspective. International Journal of Operations \& Production Management, 16, 8-23. http://dx.doi.org/10.1108/01443579610109811

Keller, A.Z., Fouad, R.H., \& Zaitri, C.K., (1991). Status and structure of just-in-time manufacturing in the UK. In Satir, A. (Ed.), Just-in-Time Manufacturing Systems. Amsterdam: Elsevier.

LEI (2003). Lean Lexicon. Brookline, MA: Lean Enterprise Institute. p. 4.

Liker, J.K. (2004). The Toyota Way: 14 Management Principles from the World's Greatest Manufacturer. New York: McGraw-Hill.

Liker, J.K., \& Morgan, J.M. (2006). The Toyota way in services: The case of lean product development. Academic Managing Perspective, 20(2), 5-20. http://dx.doi.org/10.5465/AMP.2006.20591002

Linderman, K., Schroeder, R.G., \& Choo, A. (2006). Six sigma: the role of goals in improvement teams. Journal of Operations Managemnt, 24(6), 779-790. http://dx.doi.org/10.1016/j.jom.2005.08.005

Luthra, S., Kumar, V., Kumar, S., \& Haleem, A. (2011). Barriers to implement green supply chain management in automobile industry using interpretive structural modeling technique-An Indian perspective. Journal of Industrial Engineering and Management, 4(2), 231-257. http://dx.doi.org/10.3926/jiem.2011.v4n2.p231-257

Mandal, A., \& Deshmukh, S.G. (1994) Vendor selection using interpretive structural modeling (ISM). International Journal of Operations and Production Management, 14(6), 52-59. http://dx.doi.org/10.1108/01443579410062086

McKone, K.E., Schroeder, R.G., \& Cua, K.O. (1999). Total productive maintenance: a contextual view. Journal of Operations Management, 17(2), 123-144. http://dx.doi.org/10.1016/S02726963(98)00039-4

Nakamura, M., Sakakibara, S., \& Schroeder, R. (1998). Adoption of just-in-time manufacturing methods at U.S.- and Japanese-owned plants: some empirical evidence. IEEE Transactions on Engineering Management, 45, 230-240. http://dx.doi.org/10.1109/17.704245

Panizzolo, R. (1998). Applying the lessons learned from 27 lean manufacturers. The relevance of relationships management. International Journal of Production and Economics, 55(3), 223-240. http://dx.doi.org/10.1016/S0925-5273(98)00066-8

Pattanaik, L.N., \& Sharma, B.P. (2009). Implementing lean manufacturing with cellular layout: a case study. The International Journal of Advanced Manufacturing Technology, 42, 772-779. http://dx.doi.org/10.1007/s00170-008-1629-8 
Poppendieck, M. (2002). Principles of lean thinking. Technical Report, Poppendieck LLC.

Raj, T., Shankar, R., \& Suhaib, M. (2008). An ISM approach for modelling the enablers of flexible manufacturing system: the case for India, International Journal of Production Research, 46(24), 6883-6912. http://dx.doi.org/10.1080/00207540701429926

Sage, A.P. (1977). Interpretive Structural Modeling: Methodology for Large-Scale Systems. New York, NY: McGraw-Hill.

Shah, R., \& Ward, P.T. (2003). Lean Manufacturing: context, practice bundles, and performance. Journal of Operation Management, 21(2), 129-149. http://dx.doi.org/10.1016/S0272-6963(02)00108-0

Shah, R., \& Ward, P.T. (2007). Defining and developing measures of lean production. Journal of Operations Management, 25, 785-805. http://dx.doi.org/10.1016/j.jom.2007.01.019

Skinner, W. (1974). The Focused Factory. Harvard Business Review, 52, 113-121.

Swink, M., Narasimha, R., \& Kim, S.W. (2005). Manufacturing practices and strategy integration: effect on cost efficiency, flexibility, and market-based performance. Decision Sciences, 36(3), 427-457. http://dx.doi.org/10.1111/j.1540-5414.2005.00079.x

Taj, S. (2008). Lean Manufacturing performance in china: Assessment of 65 manufacturing plants. Journal of Manufacturing Technology Management, 19(2), 217-234. http://dx.doi.org/10.1108/17410380810847927

Tompkins, J.A., White, J.A., Bozer, Y.A., Frazelle, E.H., Tanchoco, J.M.A., \& Trevino, J., (1996). Facilities Planning. 2nd ed. New York: Wiley.

Walder, J., Karlin, J., \& Kerk, C. (2007). Integrated lean thinking \& ergonomics: utilizing material handling assist device, solutions for a productive workspace. MHIA White Paper, USA.

Warfield, J.W. (1974), Developing interconnected matrices in structural modeling. IEEE Transcript on Systems. Men and Cybernetics, 4(1), 51-81.

Womack, J., \& Jones, D.T. (1994). From lean production to the lean enterprise. Harvard Business Review, 72, 93-104.

Womack, J.P., Jones, D.T., \& Roos, D. (1990). The Machine That Changed the World. New Yor: Harper Perennial.

Womak, J.P., \& Jones, D.T. (1996). Lean Thinking: Banish waste and create wealth in your corporation. New York: Simon and Schuster. 
Wong, Y.C., Wong, K.Y., \& Ali, A. (2009a). Key practices areas of lean manufacturing. Proceeding of the International Association of Computer Science and Information Technology-Spring Conference (IACSITSC 2009). Singapore, 267-271.

Worley, J.M., \& Doolen, T.L. (2006). The role of communication and management support in a lean manufacturing implementation. Management Decision, 44(2), 228-245. http://dx.doi.org/10.1108/00251740610650210

Yu Lin, C., \& Hui Ho, Y. (2008). An Empirical Study on Logistics services provider, intention to adopt Green Innovations. Journal of Technology, Management and Innovation, 3(1), 17-26.

Journal of Industrial Engineering and Management, 2013 (www.jiem.org)

Article's contents are provided on a Attribution-Non Commercial 3.0 Creative commons license. Readers are allowed to copy, distribute and communicate article's contents, provided the author's and Journal of Industrial Engineering and Management's names are included. It must not be used for commercial purposes. To see the complete license contents, please visit http://creativecommons.org/licenses/by-nc/3.0/. 